\title{
Molecular response of 4T1-induced mouse mammary tumours and healthy tissues to zinc treatment
}

\author{
MARKETA SZTALMACHOVA ${ }^{1,2}$, JAROMIR GUMULEC ${ }^{1,2}$, MARTINA RAUDENSKA ${ }^{1,2}$, HANA POLANSKA ${ }^{1,2}$, \\ MONIKA HOLUBOVA $^{1,3}$, JAN BALVAN ${ }^{1,2}$, KRISTYNA HUDCOVA ${ }^{1,2}$, LUCIA KNOPFOVA K, $^{4,5}$, \\ RENE KIZEK $^{2,6}$, VOJTECH ADAM $^{2,6}$, PETR BABULA $^{3}$ and MICHAL MASARIK ${ }^{1,2}$ \\ ${ }^{1}$ Department of Pathological Physiology, Faculty of Medicine, Masaryk University, CZ-625 00 Brno; \\ ${ }^{2}$ Central European Institute of Technology, Brno University of Technology, CZ-616 00 Brno; ${ }^{3}$ Department of Physiology, \\ Faculty of Medicine, Masaryk University, CZ-625 00 Brno; ${ }^{4}$ Department of Experimental Biology, Faculty of Science, \\ Masaryk University, CZ-625 00 Brno; ${ }^{5}$ International Clinical Research Center, Center for Biological and \\ Cellular Engineering, St. Anne's University Hospital, CZ-656 91 Brno; ${ }^{6}$ Department of Chemistry \\ and Biochemistry, Mendel University in Brno, CZ-613 00 Brno, Czech Republic
}

Received November 6, 2014; Accepted December 29, 2014

DOI: $10.3892 /$ ijo.2015.2883

\begin{abstract}
Breast cancer patients negative for the nuclear oestrogen receptor $\alpha$ have a particularly poor prognosis. Therefore, the 4T1 cell line (considered as a triple-negative model) was chosen to induce malignancy in mice. The aim of the present study was to assess if zinc ions, provided in excess, may significantly modify the process of mammary oncogenesis. $\mathrm{Zn}$ (II) ions were chosen because of their documented antitumour effects. $\mathrm{Zn}$ (II) is also known to induce the expression of metallothioneins (MT) and glutathion (GSH). A total dose of zinc sulphate per one gram of mouse weight used in the experiment was $0.15 \mathrm{mg}$. We studied the expression of MT1, MT2, TP53 and MTF-1 genes and also examined the effect of the tumour on antioxidant capacity. Tumour-free mice had significantly higher expression levels of the studied genes $(\mathrm{P}<0.003)$. Significant differences were also revealed in the gene expression between the tissues $(\mathrm{P}<0.001)$. The highest expression levels were observed in the liver. As compared to brain, lung and liver, significantly lower concentrations of MT protein were found in the primary tumour; an inverse trend was observed in the concentration of Zinc(II). In non-tumour mice, the amount of hepatic hydrosulphuryl groups significantly increased by the exposure to $\mathrm{Zn}(\mathrm{II})$, but the animals with tumour induction showed no similar trend. The primary tumour size of zinc-treated animals was $20 \%$ smaller $(\mathrm{P}=0.002)$; however, no significant effect on metastasis progression due to the zinc treatment was discovered. In conclusion, $\mathrm{Zn}$ (II) itself may mute the growth of primary breast tumours especially at their early stages.
\end{abstract}

Correspondence to: Dr Michal Masarik, Department of Pathological Physiology, Faculty of Medicine, Masaryk University, Kamenice 5, CZ-625 00 Brno, Czech Republic

E-mail: masarik@med.muni.cz

Key words: breast cancer, zinc treatment, tumour size, metallothionein, glutathione

\section{Introduction}

Breast cancer is one of the most frequent cancers in females worldwide. Patients negative for the nuclear oestrogen receptor ER- $\alpha$ (oestrogen receptor $\alpha$ ) have a particularly poor prognosis (1). Therefore, we focused on neoplastic processes induced in mice by ER- $\alpha$-negative tumours. 4T1 cell line was chosen to induce malignancy. This cell line is considered as a triple-negative model. Apart from ER- $\alpha$, this cell line lacks the protein expression of p53 (2), Wnt-5a and PgR (progesterone receptor) (3).

The 4T1 mammary carcinoma cell line was isolated by Miller et al (4) growing as an adherent epithelial type in vitro, and are characterized as murine mammary carcinoma cells. When introduced orthotopically into BALB/c mice, 4T1 cells rapidly divide and spontaneously metastasize from the mammary fat pad to several organs including liver, lungs, lymph node and brain, as well as into bones (5). Since these tumours closely imitate advanced human breast cancer, the 4T1 cell line serves as a model for stage IV of breast cancer (6).

Many epidemiological studies have dealt with a close link between higher breast tissue zinc levels and the development of breast cancer $(7,8)$. Compared with the adjacent tissues, the zinc accumulation in the tumour tissue correlated with the higher expression of cellular zinc importing proteins, prompting that tumour cells are profiting from the increase of zinc uptake (9). Furthermore, a low level of zinc efflux transporter ZnT1 was found in breast tumour cells, which caused higher levels of zinc, confirming a deregulation of zinc transport in proliferating tumour cells $(10,11)$. The expression of ZIP6, 7 and 10 (zinc-influx transporters) has been also associated with the breast cancer growth and metastasis $(8,12-14)$. Breast cancer seems to be rare in its acquisition of zinc, indicating a potential zinc demand for the development of breast malignancy (8).

Proper supervision of cytosolic zinc is highly needed for maintaining the redox status of the cells, because both excessive and reduced zinc levels can induce oxidative stress (15). 
As the excessive zinc is toxic, detoxification of this ion has a crucial role in sustaining cell homeostasis.

Zinc and other heavy metals are known to induce the expression of metallothioneins (MT) (16-19). MT expression was shown to be increased during oxidative stress $(20,21)$ to protect cells against cytotoxicity $(22,23)$ and DNA damage $(24,25)$. Metallothionein (MT) was also reported as a possible negative regulator of apoptosis (26). The main transcription factor involved in the metal regulation of $\mathrm{MT}$ expression is MRE-binding transcription factor-1 (MTF-1) (27). The free zinc is capable to bind MTF-1 and translocate it to the nucleus (28). In the nucleus, MTF-1 binds to metal responsive elements (MRE) in the MT promoter and triggers the MT expression to recoup for metal toxicity. Nevertheless, some studies have demonstrated that only breast cancer epithelial cells with the intact p53 can induce metallothionein (MT) synthesis after metal exposure $(29,30)$. Accordingly, it was also shown, that a disruption of the p53 function sensitizes breast cancer MCF-7 cells to cisplatin (31).

Consequently, the aim of the present study was to evaluate the effect of excessive zinc supplementation on metallothionein 1 and 2, metal-regulatory transcription factor 1 and TP53 expression in a mouse model with the 4T1-induced advanced breast cancer. The studied mammary tumour arose from 4T1 cells with non-functional p53 and zinc transporters set to zinc accumulation $(13,32)$; thus, the hypothesis of the toxicity of excessive zinc for the tumour tissue was tested. Furthermore, the effect of tumour on the antioxidant capacity of tissues was examined.

\section{Materials and methods}

Chemical and biochemical reagents. RPMI-1640 medium, fetal bovine serum (FBS) (mycoplasma-free), penicillin/streptomycin and trypsin were purchased from PAA Laboratories GmbH (Pasching, Austria). Phosphate-buffered saline (PBS) was purchased from Invitrogen Corp. (Carlsbad, CA, USA). Ethylenediaminetetraacetic acid (EDTA), Zinc(II) sulphate (BioReagent grade, suitable for cell cultures), RIPA buffer and all other chemicals of ACS purity were purchased from SigmaAldrich Co. (St. Louis, MO, USA), unless noted otherwise.

Cell culture and culture conditions. For in vivo and in vitro studies, the 4T1 cell line was used (cell line was kindly provided by Dr Lucia Knopfova, Masaryk University, Brno, Czech republic). The 4T1 cells grow as adherent epithelial type in vitro, and are characterized as murine mammary carcinoma cells [American Type Culture Collection (ATCC) catalogue no. CRL-2539, 2004]. The cells were cultured in RPMI-1640 medium (PAA Laboratories) supplemented with $10 \%$ fetal bovine serum (PAA Laboratories), $100 \mathrm{U} / \mathrm{ml}$ penicillin, $100 \mu \mathrm{g} / \mathrm{ml}$ streptomycin, $1 \mathrm{mM}$ sodium pyruvate, and $4.5 \mathrm{~g} / \mathrm{l}$ glucose and kept in a $37^{\circ} \mathrm{C}$ humidified incubator with $5 \% \mathrm{CO}_{2}$ in air.

Cell number quantification. Total cell content was analysed using the Casy model TT system (Roche Applied Science, Penzberg, Germany) and the following protocol: first, calibration was performed from viable and necrotic cells. For necrotic cells, $100 \mu \mathrm{l}$ cell suspension and $800 \mu \mathrm{l}$ Casy Blue solution was mixed and left for $5 \mathrm{~min}$ at room temperature. Subsequently, $9 \mathrm{ml}$ Casy Tone was added. To prepare a viable cell standard, $100 \mu \mathrm{l}$ of cell suspension was mixed with $10 \mathrm{ml}$ of Casy Tone. All subsequent measurements were made in 100x diluted $100 \mu \mathrm{l}$ cell suspension. Prior to each measurement, background was subtracted. All samples were measured in duplicates.

Zinc(II) treatment of $4 T 1$ cells. Once the cells grew up to $50-60 \%$ confluence in the culture, the growth media were replaced by fresh medium for $24 \mathrm{~h}$ to synchronize the cell growth. The 4T1 cells were then treated with zinc sulphate $(0-100 \mu \mathrm{M})$ in fresh medium for $48 \mathrm{~h}$.

MTT viability assay. The MTT assay was used to determine cell viability. The suspension of cells in the growth medium was diluted to a density of 5,000 cells $/ 1 \mathrm{ml}$ and $200 \mathrm{ml}$ were transferred to wells 2-11 of standard microtiter plates. The medium $(200 \mathrm{ml})$ was added to the first and to the last column (1 and 12). The plates were incubated for 2 days at $37^{\circ} \mathrm{C}$ to ensure the cell growth. The medium was removed from columns 2 through to 11. Columns 3-10 were filled with $200 \mu \mathrm{l}$ of the medium containing different concentrations of zinc $(0,25,50,75$ and $100 \mu \mathrm{M})$. As a control, columns 2 and 11 were fed with the medium only. The plates were incubated for $24 \mathrm{~h}$; then, the medium was removed and exchanged with a fresh medium, daily three times. After that, columns 1-11 were fed with $200 \mathrm{ml}$ of the medium with $50 \mathrm{ml}$ of MTT $(5 \mathrm{mg} / \mathrm{ml}$ in PBS) and incubated for $4 \mathrm{~h}$ in a humidified atmosphere at $37^{\circ} \mathrm{C}$, wrapped in the aluminium foil. After that, the mediumMTT was exchanged with $200 \mathrm{ml}$ of $99.9 \%$ DMSO to dissolve MTT-formazan crystals. Then, $25 \mathrm{ml}$ of glycine buffer was added to all wells with DMSO and the absorbance was recorded at $570 \mathrm{~nm}$ (VersaMax microplate reader; Molecular Devices, Sunnyvale, CA, USA) (33).

Real-time impedance based cell growth and proliferation assay. The impedance-based real-time cell analysis (RTCA) $\mathrm{xCELLigence} \mathrm{system} \mathrm{was} \mathrm{used} \mathrm{according} \mathrm{to} \mathrm{the} \mathrm{instructions} \mathrm{of}$ the supplier (Roche Applied Science and ACEA Biosciences, San Diego, CA, USA). The xCELLigence system consists of four main components: RTCA DP station, RTCA computer with integrated software and disposable E-Plate 16. Firstly, the optimal seeding concentration for proliferation and cytotoxic assay was determined. Optimal response was found in the well containing 10,000 cells. After seeding a total number of cells in $200 \mathrm{ml}$ of medium to each well in E-Plate 16, the attachment and proliferation of the cells were monitored every $15 \mathrm{~min}$. Duration of all experiments was $200 \mathrm{~h}$. Results are expressed as relative impedance using manufacturer's software (Roche Applied Science and ACEA Biosciences) (33).

Tumour development and zinc supplementation. Eightweek-old $40 \mathrm{Balb} / \mathrm{c}$ female mice (weight 21-24 g) were equally distributed to $2 \times 2$ groups according to the tumour presence (tumour/control) and zinc supplementation (supplemented/not supplemented). The 4T1 metastatic breast cancer cell line was used to induce the neoplastic process. The 4T1 cells used in the tumour development study were freshly harvested at $70 \%$ confluence. The 4T1 cells $\left(1 \times 10^{5}\right)$ in $20 \mu \mathrm{l}$ of PBS and Matrigel 
(1:1 ratio) were administered into the fourth mammary fat pad under general anesthesia (1\% Narkamon $+2 \%$ Rometar $0.5 \mathrm{ml} / 100 \mathrm{~g}$ of weight).

The intraperitoneally administered dose of zinc was a half-LD ${ }_{50}$ dose as determined by Domingo et al (34) (total dose $0.15 \mathrm{mg} / \mathrm{g}$ of zinc sulphate). A total amount of $0.15 \mathrm{mg} / \mathrm{g}$ of zinc sulphate divided into 4 doses $(0.025+0.05+0.05+$ $0.025 \mathrm{mg} / \mathrm{g}$ ) was applied to the mice intraperitoneally. The mice were fed ad libitum, and observed daily. The cages were kept in a climate-controlled room and cleaned weekly. Tumour volume (length $\mathrm{x}$ width ${ }^{2} \mathrm{x} 0.5$ ) was measured twice per week following the equation utilized in similar tumour development studies $(35,36)$. After 1 month, the animals were sacrificed, the tumour weight and volume were measured and the following organs were isolated: primary tumour, brain, liver, lung, spleen and kidney. RNA was isolated by using TriPure reagent (Roche, Boston, MA USA) and qRT-PCR was performed with $\beta$-actin as housekeeping gene.

The use of the animals followed the European Community Guidelines as accepted principles for the use of experimental animals. The experiments were performed with the approval of the Ethics Commission at the Faculty of Medicine, Masaryk University, Brno, Czech Republic.

Tissue sample preparation. Approximately $0.01 \mathrm{~g}$ of the tissue in $500 \mathrm{ml}$ of PBS was mechanically disintegrated using UltraTurrax T8 homogenizer (IKA-Werke, Staufen, Germany) placed in an ice bath for $3 \mathrm{~min}$ at 25,000 rpm.

The homogenates were kept at $99^{\circ} \mathrm{C}$ in a thermomixer (Eppendorf 5430; Eppendorf, Hamburg, Germany) for $15 \mathrm{~min}$ with shaking. The denatured homogenates were centrifuged at $4^{\circ} \mathrm{C}, 15,000 \mathrm{x}$ g for $30 \mathrm{~min}$ (Eppendorf 5402; Eppendorf). Heat treatment effectively denatures and removes thermolabile and high molecular mass proteins from the samples. The prepared samples were used for metallothionein and sulfhydryl group analyses.

Electrochemical detection of Zinc(II) ions. Electrochemical analyser Model Metrohm AG (Herisau, Switzerland) was used for the determination of $\mathrm{Zn}$ (II). The analyser (757 VA Computrace) employs a conventional three-electrode configuration with the hanging mercury drop electrode (HMDE) as a working electrode: $0.4 \mathrm{~mm}^{2}, \mathrm{Ag} / \mathrm{AgCl} / 3 \mathrm{M} \mathrm{KCl}$ as a reference electrode and a platinum auxiliary electrode. Differential pulse voltammetric measurements were carried out under the following conditions: deoxygenating with argon for $60 \mathrm{sec}$; deposition potential: $-1.3 \mathrm{~V}$; time of deposition: $240 \mathrm{sec}$; start potential: $-1.3 \mathrm{~V}$; end potential: $0.15 \mathrm{~V}$; pulse amplitude: $0.025 \mathrm{~V}$; pulse time: $0.04 \mathrm{sec}$; step potential: $5.035 \mathrm{mV}$; time of step potential: $0.3 \mathrm{sec}$. For more details see Masarik et al (33).

RNA isolation and reverse transcription. High pure total-RNA isolation kit (Roche) was used for isolation. The medium was removed and the samples were twice washed with $5 \mathrm{ml}$ of icecold PBS. The cells were scraped off, transferred to clean tubes and centrifuged at $20,800 \times \mathrm{g}$ for $5 \mathrm{~min}$ at $4^{\circ} \mathrm{C}$. After this step, a lysis buffer was added and RNA isolation was carried out according to manufacturer's instructions. The isolated RNA was used for cDNA synthesis. RNA (600 ng) was transcribed using Transcriptor first strand cDNA synthesis kit (Roche), which was applied according to manufacturer's instructions. The cDNA $(20 \mu \mathrm{l})$ prepared from the total-RNA was diluted with RNase-free water to $100 \mu \mathrm{l}$ and the amount of $5 \mu \mathrm{l}$ was directly analysed by using the 7500 RT-PCR system (Applied Biosystems).

Quantitative real-time polymerase chain reaction. q-PCR was performed in triplicate using the TaqMan gene expression assay system with the 7500 RT-PCR system (Applied Biosystems) and the amplified DNA was analysed by the comparative $\mathrm{Ct}$ method using $\beta$-actin as an endogenous control for metallothionein MT2, MT1, MTF-1 and TP53 gene expression quantification. The primer and probe sets for $\beta$-actin (assay ID: Mm00607939_s1), MT2 (Mm04207591_g1), MT1 (Mm00496660_g1), TP53 (Mm01731290_g1) and MTF-1 (Mm00485274_m1) were selected from TaqMan gene expression assays (Life Technologies, Waltham, MA, USA). q-PCR was performed under the following amplification conditions: total volume of $20 \mu \mathrm{l}$, initial incubation at $50^{\circ} \mathrm{C} / 2 \mathrm{~min}$ followed by denaturation at $95^{\circ} \mathrm{C} / 10 \mathrm{~min}$, then 45 cycles at $95^{\circ} \mathrm{C} / 15 \mathrm{sec}$ and at $60^{\circ} \mathrm{C} / 1 \mathrm{~min}$.

Electrochemicaldetection of metallothionein. Electrochemical detection was used to quantify metallothionein in the thermolysate samples. The detection was carried out using Autolab Analyser (Eco Chemie, Utrecht, The Netherlands) with the classic three-electrode arrangement using differential pulse voltammetry Brdicka reaction. The analysed sample was accumulated on the surface of a working electrode, which was represented by the hanging mercury drop electrode. After the accumulation, the detection proceeded in a supporting electrolyte containing cobaltic (cobalt ${ }^{3+}$ ) salt in ammonia buffer of $\mathrm{pH} 9.6$ (37).

Analysis of the total content of sulfhydryl groups. The concentration of sulfhydryl groups (SH groups) in the tissues was determined using $0.2 \mathrm{mmol} / 1$ 5,5'-dithiobis (2-nitrobenzoic acid) (DTNB) reported by Ellmann (38) (the intra-assay CV was $3.5 \%$ and the inter-assay $\mathrm{CV}$ was $5.5 \%$ ). Total sulfhydryl group content values were expressed in $\mu \mathrm{mol} / \mathrm{g}$ of proteins.

Statistical analysis. The data were tested for normality and the log-normal distributed data were recalculated. Factorial ANOVA and the Bonferroni post-hoc test were used for the statistical analysis. Pearson correlations were performed to reveal dependence between the variables. Software Statistica 12 (StatSoft, Inc., Tulsa, OK, USA) was employed to perform the statistical analysis. P-level of $<0.05$ was considered statistically significant.

\section{Results}

In vitro effects on the $4 T 1$ cell line

Effect of zinc(II) on $4 T 1$ viability. In the first step, an analysis of 4T1 cell line viability after Zinc(II) treatment was performed to adjust the optimal dose administered to animals in the next step. For the proliferation and viability assay, zinc sulphate treatment concentrations were optimized as follows: 0 (control), $25,50,75$ and $100 \mu \mathrm{M}$. Consequently, $\mathrm{IC}_{50}$ of zinc sulphate 


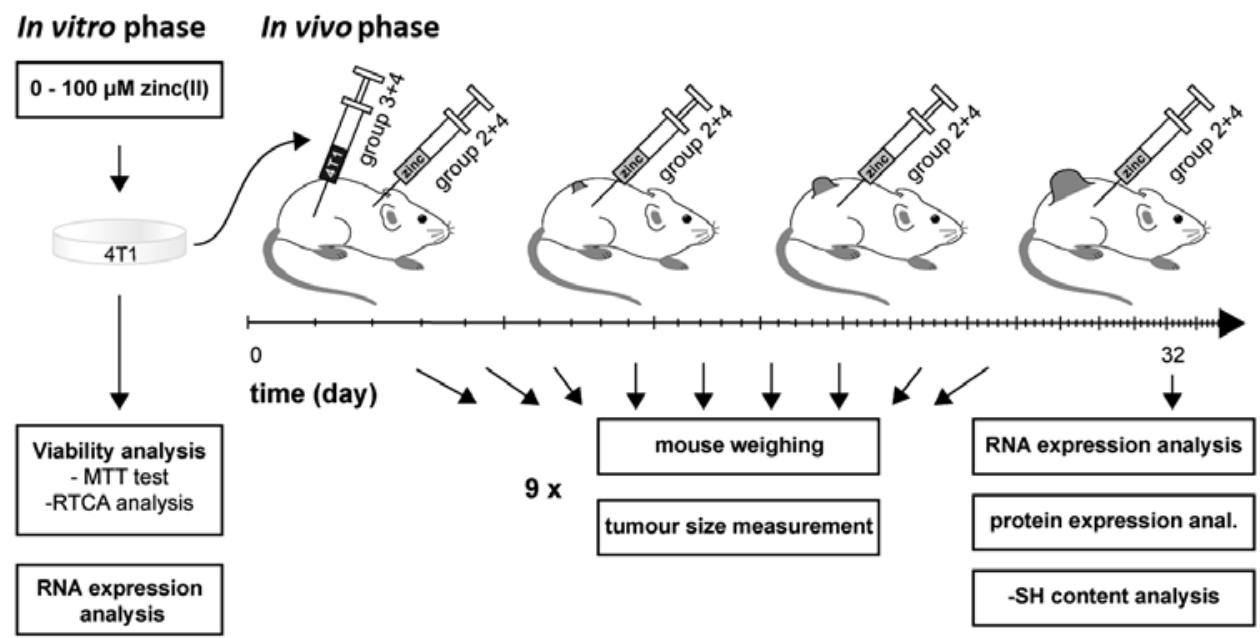

Figure 1. Experimental flow chart. Animals were divided into 4 groups: no zinc treatment, no tumour induction (group 1); zinc-treated, no tumour induction (group 2); no zinc treatment, tumour induction (group 3); zinc treatment and tumour induction (group 4); (group 4 is shown). Zinc was administered in 4 doses; the animals were weighed and the tumour size was measured 9 times during the experiment. After the experiment, selected tissues were analysed.

for the $4 \mathrm{~T} 1$ cell line was determined. The $\mathrm{IC}_{50}$ value obtained from the MTT cytotoxicity assay was $83.7 \mu \mathrm{M}$ (Fig. 2A). The $\mathrm{IC}_{50}$ value obtained by using the impedance-based real-time cell analysis (RTCA) system was also determined for the same period of time as the MTT assay ( $48 \mathrm{~h}$ after the beginning of the experiment). The $\mathrm{IC}_{50}$ value was $52.8 \mu \mathrm{M}$ (Fig. $2 \mathrm{~B}$ ).

Effect of zinc(II) on $4 T 1$ gene expression. In the next step, the expression of $M T 1$ and $M T 2$ in the 4T1 cell line after the zinc sulphate treatment was detected. The following Zinc(II) concentrations were used to analyse the effect on expression: $0,25,50,75$ and $100 \mu \mathrm{M}$. Using one-way ANOVA, no significant effect of the 'zinc concentration' factor was determined for $M T 1$ and $M T 2$ expression. No correlation between $M T 1$ or $M T 2$ expression and zinc sulphate concentration was found (Fig. 2C).

\section{Mouse models of breast tumours}

Effect of zinc(II) on animal weight. Animals were divided into the following groups: i) control, ii) control administered with Zinc(II), iii) 4T1-induced tumour mice, iv) 4T1-induced tumour mice administered with zinc. The experimental scheme is illustrated in Fig. 1. To verify whether the administered Zinc(II) doses cause symptoms of intoxication, the mice were weighed during the experiment. There was no significant trend during the treatment. Additionally, one-way ANOVA did not reveal any significant weight difference between the groups (Fig. 3A). Based on this finding it can be concluded, that Zinc(II) does not have any serious whole-body effects.

Effect of Zinc(II) on tumour size. Tumours arose in all animals with the $4 \mathrm{~T} 1$ breast cancer cell application, and no tumour was found in animals without the 4T1 tumour induction. The autopsy of organs revealed a clear progression of metastases to liver, lungs, bones and spleen with occasional metastases to brain and intestines in both groups (zinc sulphate untreated or treated).

Concurrently, the tumour size was measured during the experiment to verify whether the Zinc(II) administration

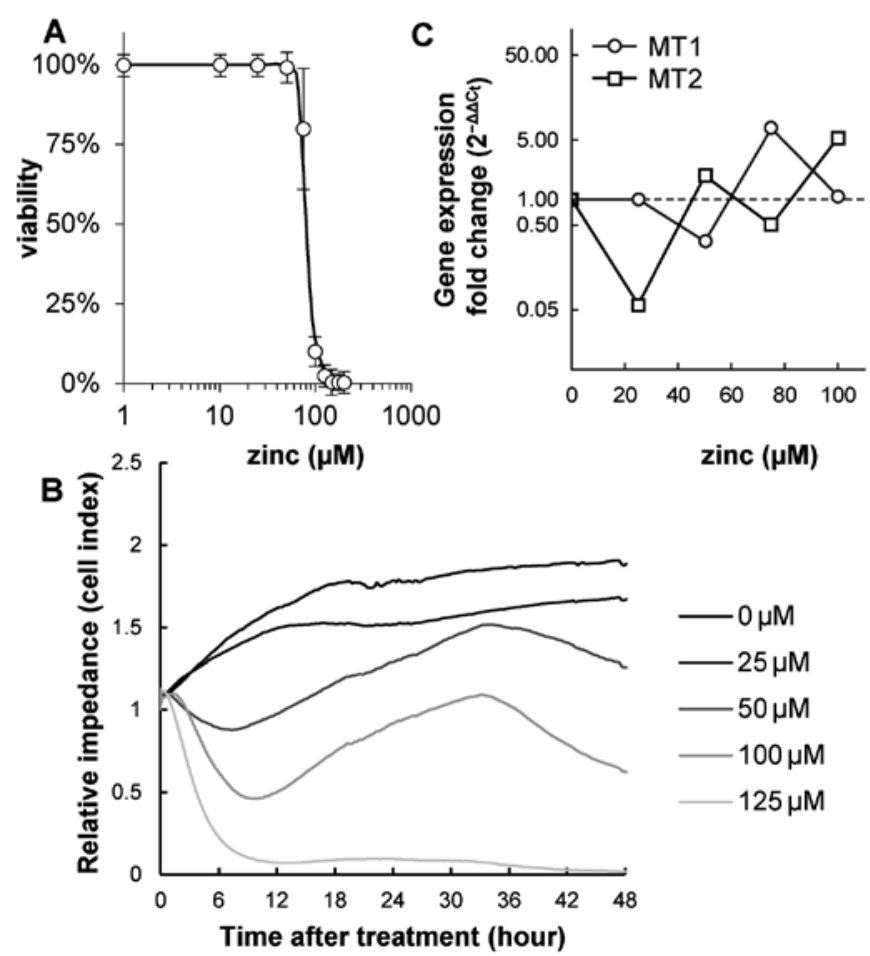

Figure 2. 4T1 cell line analysis. Analysis of viability after Zinc(II) treatment using MTT (A) and real-time impedance-based cell analysis system (B). For $\mathrm{IC}_{50}$ refer to the Results. (C) Analysis of MT1 and MT2 gene expression after the zinc treatment. No significant trend was observed.

affects the tumour tissue. Using one-way ANOVA after the adjustment to the treatment time, there was a significant effect of the treatment group, $\mathrm{F}(1,137)=7.2804, \mathrm{P}=0.008$ ). Tumour reduction up to $28 \%$ was observed in the zinc-treated subjects (Fig. 3B).

Gene expression. The effect of Zinc(II) supplementation was analysed for association with the gene expression profile of metallothionein 1 and 2 (MT-1 and MT-2), metallothionein transcription factor MTF-1 and TP53. The effect of tumour 

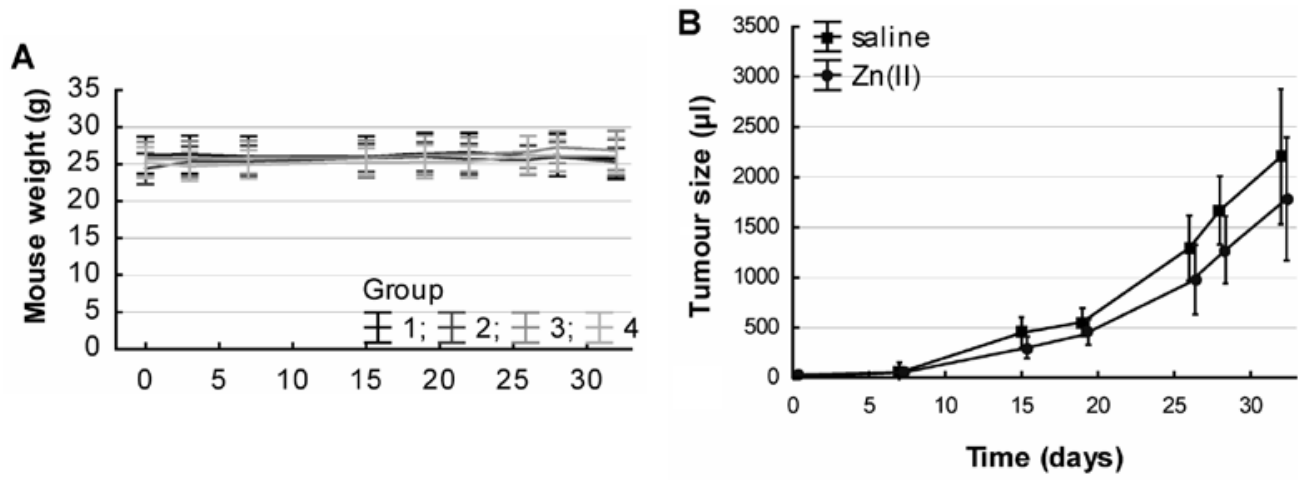

Figure 3. (A) Mouse weight and tumour size (B) measurements. Data are displayed as a mean \pm SD. Significant difference in the tumour size was observed between groups 3 (tumour induced, no zinc treatment) and 4 (tumour induced, zinc-treated) after the adjustment for time.
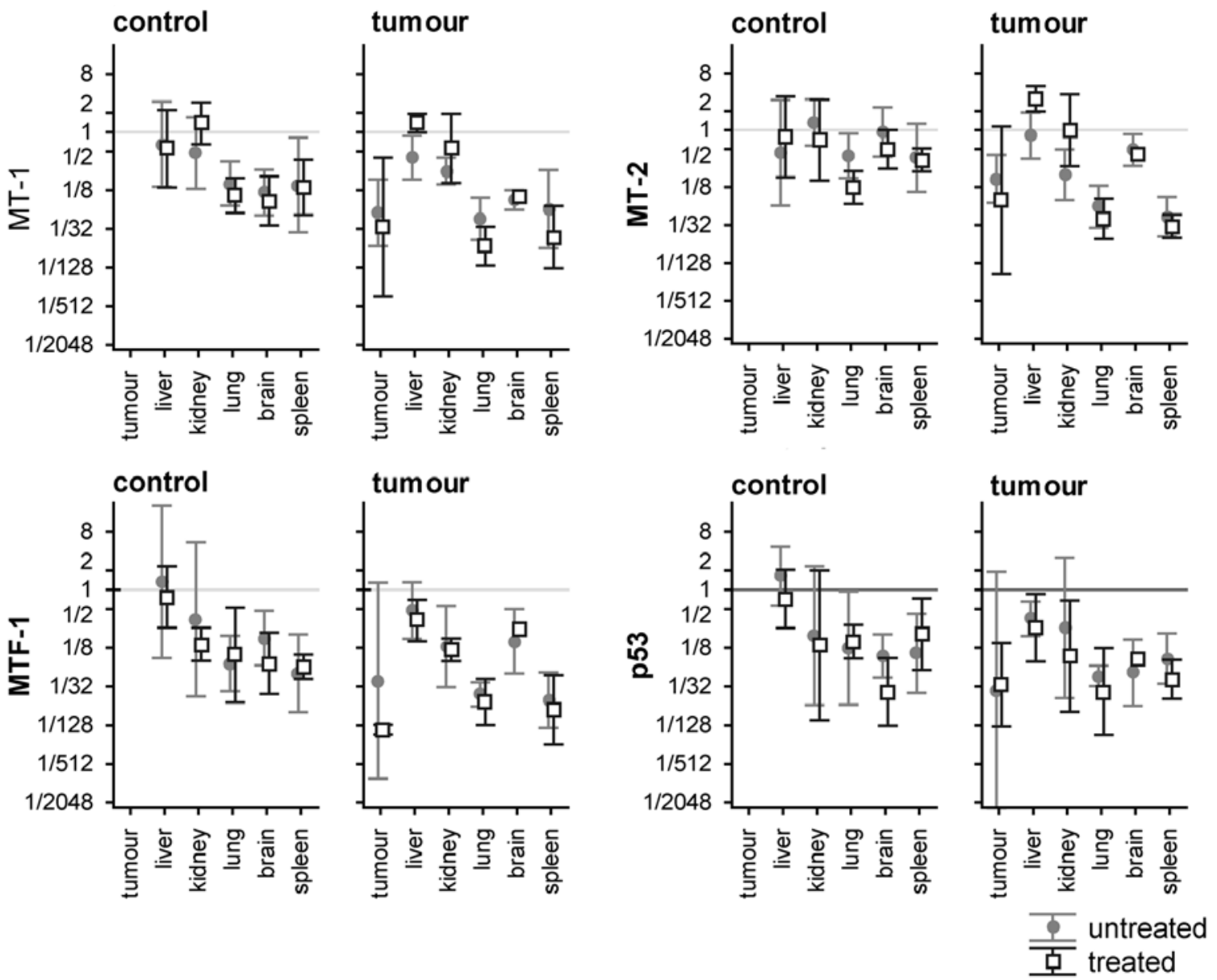

Figure 4. Relative expression levels of genes in selected tissues. Expression related to untreated liver tissue in mice without induced tumours. For details of the statistical significance refer to the Results. Data are the mean and 95\% confidence intervals.

induction, Zinc(II) treatment, and tissue type on gene expression was analysed.

Using multivariate ANOVA, we observed a significant effect of the tissue type on the gene expression level, $\mathrm{F}(20$, 481.86)=12.96, $\mathrm{P}<0.001$ after the adjustment of all other variables. As expected, the highest expression levels of all the above-mentioned genes were observed in hepatic and kidney tissues. On the other hand, the expression of all genes was significantly lower in the lung tissue, spleen and in the primary tumour as assessed by Bonferroni post-hoc testing.
Using multivariate ANOVA, there was a significant effect of tumour induction on the gene expression level, $\mathrm{F}(4$, $145)=11.36, \mathrm{P}<0.001$ after the adjustment of all other variables; the expression of all of the above-mentioned genes was lower in the tumourous tissues. Consequently, the effect of treatment was analysed using the same test after the adjustment of all other variables. However, the expression of the selected genes did not differ significantly in relation to this factor, $\mathrm{F}(4,145)=1.40, \mathrm{P}=0.24$. Therefore, a combined effect of the Zinc(II) treatment, tumour induction and tissue type was 
A control

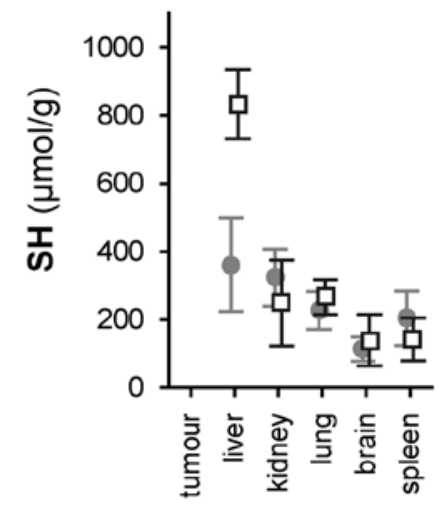

C

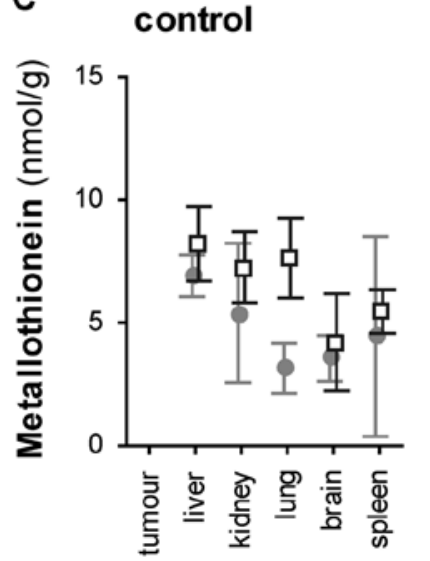

tumour

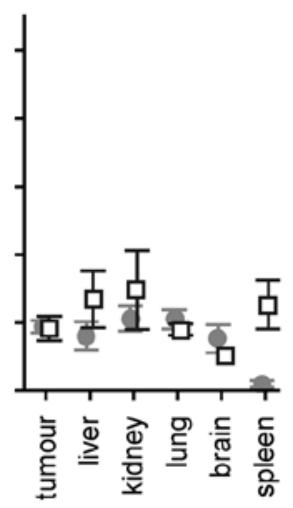

tumour

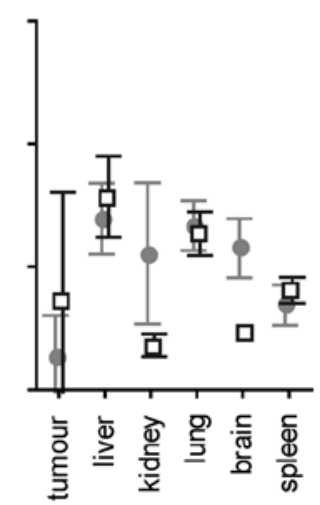

B

control

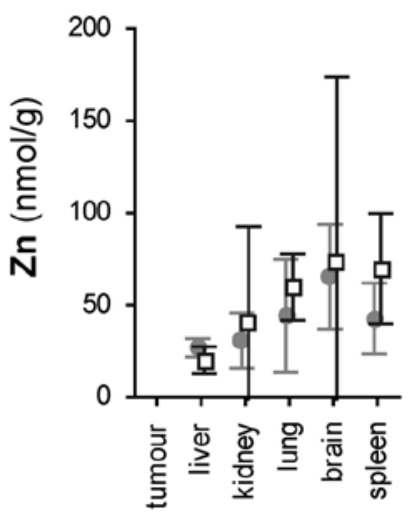

tumour

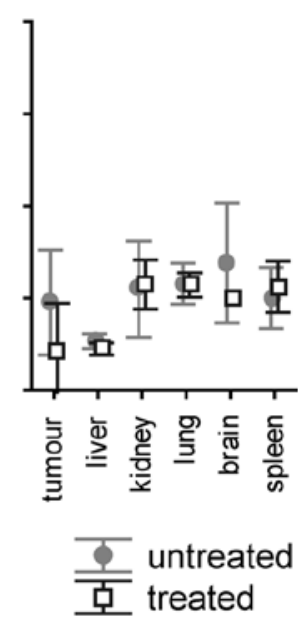

D

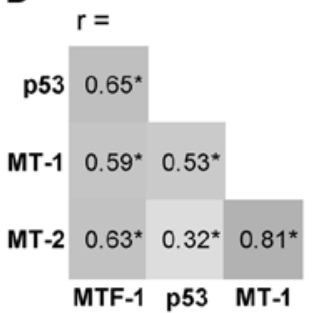

E

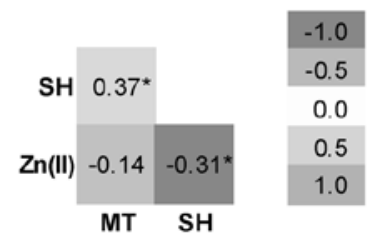

Figure 5. (A) Analysis of sulfhydryl group content, (B) zinc level and (C) metallothionein protein expression in selected tissues. Correlation between parameters at RNA level (D) and (E) correlation between zinc content, metallothionein protein expression and sulfhydryl group content. Data are the means and 95\% confidence intervals. Correlations displayed as Pearson $\mathrm{r}$. Asterisk indicates a significance level at $\mathrm{P}<0.05$.

analysed in relation to gene expression to reveal whether the effect of treatment is recorded only in the individual types of tissues or only in the tumour-induced cases.

The ANOVA test revealed, that the expression of genes is significantly affected by the combined effect of Zinc(II) treatment*tumour induction*tissue, $\mathrm{F}(20,481,86)=1.64$, $\mathrm{P}=0.04$ (Fig. 4). To reveal the trends of individual genes, the Bonferroni post-hoc test was performed using the 'tissue-bytissue' manner. There was a strong co-expression pattern of the genes with significant positive correlations; all correlations were significant at $\mathrm{P}<0.01$ with the highest correlation observed between $M T 1$ and $M T 2(\mathrm{r}=0.82)$ and the lowest (but still significant) correlation observed between TP53 and $M T 2$ (r=0.32) (Fig. 5D). With regard to the metallothionein expression, significant differences were recorded in the lung tissue; animals with induced tumours had significantly lower $M T 1$ and $M T 2$ levels than the controls. While no other 'intra-tissue' trends were observed in the $M T 1$ isoform, we recorded significant trends of $M T 2$ levels in the spleen and liver tissue. Similarly as in the lungs, the MT2 expression was significantly lower in the tumourous tissue than in the control animals. By contrast, an inverse trend was apparent in the liver tissue; the expression of MT2 in untreated controls was significantly lower than in treated mice with the induced tumours.
In summary, the expression levels of MT, TP53 and MTF-1 are affected mostly by the tissue type. Tumour induction and Zinc(II) treatment affect the expression of individual genes only, namely $M T 1$ and $M T 2$.

Analysis of sulfhydryl group compounds, MT protein expression and zinc(II) ions. Experiments analysing the RNA levels pointed to a significant variation of MT in relation to tumour induction. MTs have a high content of cysteine residues that bind various heavy metals, therefore an analysis of sulfhydryl group content was carried out. The total-SH content does not reflect only MT, but also other redox-active compounds, reduced glutathione (GSH) in particular. Thus, MT was determined electrochemically. In addition, Zinc(II) levels were detected.

A correlation between these variables was determined. While only a weak positive correlation was found between the content of $-\mathrm{SH}$ groups and MT ( $\mathrm{r}=0.37$ at $\mathrm{P}<0.001)$, Zinc(II) correlated with the $-\mathrm{SH}$ group content negatively, $\mathrm{r}=-0.31$ at $\mathrm{P}<0.001$ (Fig. 5E). Thus, $-\mathrm{SH}$ and metallothionein were interpreted separately in the following statistical tests.

Similarly to the analysis of gene expression, the effect of tissue on the concentration of sulfhydryl groups (-SH), metallothionein protein (MT) and Zinc(II) was assessed using ANOVA. Similar to the mRNA level, the concentrations of 
these substances differed between the tissues. While there were significantly lower concentrations of MT in the primary tumour as compared to brain, lung and liver, an inverse trend was observed in the concentration of Zinc(II): the concentration of Zinc(II) was significantly higher in the tumorous tissue compared to that recorded in the liver.

Consequently, the effect of tumour induction of the level of MT, -SH and zinc was assessed. A significantly 1-5-fold lower -SH content was identified in animals with the induced tumours using post-hoc testing. MT and zinc did not differ significantly.

There was a significant effect of the treatment on the metallothionein protein level, -SH groups and zinc level, $\mathrm{F}(3$, 113) $=4.90, \mathrm{P}=0.003$ (Fig. 5A-C). Post-hoc testing revealed a significantly 1.4-fold higher content of -SH groups in treated animals at $\mathrm{P}<0.05$. This trend was highlighted namely when the combined effect of treatment*tissue type*tumour induction on the $-\mathrm{SH}$ concentration was analysed (Fig. 5A). On the other hand, the metallothionein protein and zinc levels were also elevated in the treated animals, but below the level of statistical significance.

\section{Discussion}

The aim of the present study was to assess if zinc ions provided in excess may significantly modify the process of mammary oncogenesis in mice. $\mathrm{Zn}$ (II) ions were chosen because of their documented antitumour effect and inhibition of copper ions, which are known as pro-oxidant and angiogenic factors (32,39-41). Previously, it was also demonstrated in breast cancer cells that zinc ions can inhibit NF- $\kappa \mathrm{B}$, which is exceedingly activated in breast cancer with a hormone independent phenotype $(42,43)$. Moreover, zinc may have a direct impact on cell death in prostate cancer cells (44). Even physiological concentrations of zinc cause quick discharge of cytochrome $c$ from the inner membrane of mitochondria. Thereafter, cytochrome $c$ triggers the caspase pathway and activates apoptosis (45). Zinc is also involved in epigenetic mechanisms $(46,47)$. From the epigenetic perspective, zinc deficiency leads to decreased DNA and histone methylation (48), which may be due to the fact that histone deacetylases and histone lysine methyltransferases are zinc-dependent enzymes (49-52). Inhibitors of histone deacetylase were also shown to reactivate the oestrogen receptor in oestrogen receptor-negative breast cancer cells (53). Other effects of zinc ions were expected through the oxidative stress and metallothionein-mediated pathways.

In the present study, the intraperitoneally administered dose of zinc was a half- $\mathrm{LD}_{50}$ dose as determined by Domingo et al (34) (total dose $0.15 \mathrm{mg} / \mathrm{g}$ of zinc sulphate). Using different dietary zinc doses at different time periods, Hou et al (40) found that doses $<1 \mathrm{mg} / \mathrm{g}$ do not result in anorexia and body weight loss in mice. Accordingly, zinc doses administrated in our study caused no symptoms of intoxication, and there was no body weight loss in the treated mice as compared with the control group. The studied mammary tumour arose from 4T1 cells with non-functional p53 and zinc transporters set to zinc accumulation (13), thus, the hypothesis about the toxicity of excessive zinc for the tumour tissue was tested. Fan and Cherian (29) and Ostrakhovitch et al (30) demonstrated that only breast cancer epithelial cells with the intact p53 can induce metallothionein (MT) synthesis after the metal exposure. In agreement with these findings, no significant changes in $M T 1$ or MT2 mRNA expression after the zinc sulphate treatment of the 4T1 cell culture were found. No correlation between $M T 1$ or $M T 2$ expression and zinc sulphate concentration was established. Neither was a significant change in MT1, MT2, TP53 and MTF1 gene expression found in the tumour tissue after Zinc(II) exposure. The tumour-free mice had significantly higher expression levels of the studied genes $(\mathrm{P}<0.003)$.

Significant differences were also revealed among the tissues $(\mathrm{P}<0.001)$. The highest expression levels were observed in liver, which indicates the important role of this organ in the oxidative stress processes and in the homeostasis of metal ions. In the tumour-free mice, the amount of hepatic sulfhydryl groups was significantly increased by the exposure to zinc sulphate, but animals with tumour induction did not show a similar trend. In contrast, no such trend was observed in metallothionein (compare Fig. 5A and C). The difference as well as the relatively weak correlation between MT and -SH can be elucidated as follows: GSH is an important non-protein -SH compound, together with MT, which includes an unusually high cysteine content, these two -SH substances represent important defence against stress (54). This is why the total -SH content reflects mostly those compounds. Thus, the zincinduced -SH elevation reflects an increase of GSH content in liver and emphasizes the importance of liver tissue in the regulation of zinc(II).

The above confirms the significant effect of breast tumour on the antioxidant capacity of the whole organism and shows the inability of the exhausted body to cope with oxidative stress conditions. According to Feng et al (55) in patients with malignant breast cancer the overall antioxidant/oxidant balance is significantly disrupted as compared with healthy controls. Kasapovic et al (56) also showed that breast carcinoma is associated with elevated plasma lipid peroxidation and with a concomitant decrease in the antioxidant capacity of blood cells.

In conformity with our hypothesis, the primary tumour size of zinc-treated animals was $23 \%$ smaller $\mathrm{F}(1,114)=9.71$, $\mathrm{P}=0.02$ using ANOVA after adjustment for time; however, no significant effect on metastasis progression due to the zinc treatment was discovered. As a further confirmation of excessive zinc toxicity for breast cancer cells, Al-Qubaisi et al (57) found that the $\mathrm{IC}_{50}$ value of NiZn ferrite nanoparticles in normal breast MCF-10 cells was almost 15 times higher than that in breast cancer MCF-7 cells lines. Surprisingly, no significant changes in the final zinc accumulation between tissues or due to the zinc treatment or tumour bearing were found. Nevertheless, Woo and $\mathrm{Wu}$ (32) reported that MNU-induced mammary tumourigenesis resulted in a zinc concentration in the mammary tumour higher than in the mammary gland, whereas the body zinc-distribution profile was not affected. Skrajnowska et al (58) demonstrated that rat diet supplemented with zinc or copper increased the $\mathrm{Cu}$ content in the cancerous tissue as compared to normal tissue but did not lead to changes in the final $\mathrm{Zn}$ levels. We hypothesize that the tumour cells with the highest zinc accumulation succumbed to cell death, which is why the final zinc levels remained unchanged. 
In contrast to our study, some other studies have shown that the growth of mammary carcinomas is suppressed rather by zinc depletion (59-61). McQuity et al (62) discovered that mammary tumour growth was markedly inhibited in the zincdeficient group and only slightly inhibited in the zinc-adequate and zinc-excess pair-fed groups of rats. This difference might be due to the different cell lines used in the studies. Pories et al (60), Dewys et al (61) and McQuity et al (62) used Walker 256 cells. Mills et al (59) used R323OAC mammary adenocarcinoma cells. Walker 256 cells arose spontaneously in the mammary gland of a pregnant albino rat and were shown to be of hematopoietic (i.e., monocytoid) origin (63). The R3230AC rat mammary adenocarcinoma is a transplantable tumour model, which can be grown in vitro, but unlike the 4T1 cells, it does not metastasize spontaneously (64). It seems there are no significant differences between the normal rat mammary tissue and the oestrogen receptor-deficient R323OAC tumour with regard to the number of prolactin binding sites, specificity of binding, or the affinity of the receptor for prolactin (65). In contrast, 4T1 cells represent a typical triple-negative breast cancer cell line (ER-, $\left.\mathrm{PR}^{-}, \mathrm{HER} 2^{-}\right)$(66), they are highly metastatic, display predominantly epithelial characteristics, though they also express the mesenchymal marker VIM (67). Similar to human breast cancer, 4T1 metastatic disease spreads from the primary tumour. Also, the progressive dissemination of 4T1 metastases to lymph nodes and other organs is analogous to human breast cancer (68). This evidence indicates that 4T1 should be a more favourable breast cancer model for the assessment of zinc treatment. According to the present study and to the results of other authors $(8,69,70)$, zinc itself may mute the growth of primary breast tumours especially at the early stages.

\section{Acknowledgements}

The financial support from doc CEITEC 02/2012 (JG), MUNI/ A/1003/2013, European Regional Development Fund - project FNUSA-ICRC (CZ.1.05/1.1.00/02.0123) and Project for Conceptual Development of Research Organization (Faculty of Medicine, Masaryk University - ROZV/24/LF5/2014) is greatly acknowledged.

\section{References}

1. Giacinti L, Claudio PP, Lopez M and Giordano A: Epigenetic information and estrogen receptor alpha expression in breast cancer. Oncologist 11: 1-8, 2006.

2. Yerlikaya A, Okur E and Ulukaya E: The p53-independent induction of apoptosis in breast cancer cells in response to proteasome inhibitor bortezomib. Tumor Biol 33: 1385-1392, 2012.

3. Ford CE, Ekstrom EJ and Andersson T: Wnt-5a signaling restores tamoxifen sensitivity in estrogen receptor-negative breast cancer cells (Retracted Article. See vol 107, pg 22360, 2010). Proc Natl Acad Sci USA 106: 3919-3924, 2009.

4. Miller FR, Miller BE and Heppner GH: Characterization of metastatic heterogeneity among subpopulations of a singlemouse mammary-tumor: heterogeneity in phenotypic stability. Invasion Metastasis 3: 22-31, 1983.

5. Tao K, Fang M, Alroy J and Sahagian GG: Imagable 4T1 model for the study of late stage breast cancer. BMC Cancer 8: 228, 2008.

6. Aslakson CJ and Miller FR: Selective events in the metastatic process defined by analysis of the sequential dissemination of subpopulations of a mouse mammary-tumor. Cancer Res 52: 1399-1405, 1992.
7. Cui Y, Vogt S, Olson N, Glass AG and Rohan TE: Levels of zinc, selenium, calcium, and iron in benign breast tissue and risk of subsequent breast cancer. Cancer Epidemiol Biomark Prev 16: $1682-1685,2007$

8. Grattan BJ and Freake HC: Zinc and cancer: implications for LIV-1 in breast cancer. Nutrients 4: 648-675, 2012.

9. Chasapis CT, Loutsidou AC, Spiliopoulou CA and Stefanidou ME: Zinc and human health: an update. Arch Toxicol 86: 521-534, 2012.

10. Liuzzi JP and Cousins RJ: Mammalian zinc transporters. Annu Rev Nutr 24: 151-172, 2004.

11. Lee R, Woo W, Wu B, Kummer A, Duminy H and Xu Z: Zinc accumulation in $\mathrm{N}$-methyl-N-nitrosourea-induced rat mammary tumors is accompanied by an altered expression of ZnT-1 and metallothionein. Exp Biol Med 228: 689-696, 2003.

12. Taylor KM, Morgan HE, Johnson A, Hadley LJ and Nicholson RI: Structure-function analysis of LIV-1, the breast cancer-associated protein that belongs to a new subfamily of zinc transporters. Biochem J 375: 51-59, 2003.

13. Kagara N, Tanaka N, Noguchi S and Hirano T: Zinc and its transporter ZIP10 are involved in invasive behavior of breast cancer cells. Cancer Sci 98: 692-697, 2007.

14. Taylor KM, Vichova P, Jordan N, Hiscox S, Hendley R and Nicholson RI: ZIP7-mediated intracellular zinc transport contributes to aberrant growth factor signaling in antihormone-resistant breast cancer cells. Endocrinology 149: 4912-4920, 2008.

15. Maret W: Zinc coordination environments in proteins as redox sensors and signal transducers. Antioxid Redox Signal 8: 1419-1441, 2006.

16. Gumulec J, Masarik M, Krizkova S, et al: Insight to physiology and pathology of zinc(II) ions and their actions in breast and prostate carcinoma. Curr Med Chem 18: 5041-5051, 2011.

17. Gumulec J, Masarik M, Adam V, Eckschlager T, Provaznik I and Kizek R: Serum and tissue zinc in epithelial malignancies: a meta-analysis. PLoS One 9: e99790, 2014.

18. Gumulec J, Raudenska M, Adam V, Kizek R and Masarik M: Metallothionein - immunohistochemical cancer biomarker: a meta-analysis. PLoS One 9: e85346, 2014.

19. Holubova M, Axmanova M, Gumulec J, et al: KRAS NF-kappa $\mathrm{B}$ is involved in the development of zinc resistance and reduced curability in prostate cancer. Metallomics 6: 1240-1253, 2014.

20. Ruttkay-Nedecky B, Nejdl L, Gumulec J, et al: The role of metallothionein in oxidative stress. Int J Mol Sci 14: 6044-6066, 2013.

21. Sato M and Bremner I: Oxygen free-radicals and metallothionein. Free Radic Biol Med 14: 325-337, 1993.

22. Masarik M, Gumulec J, Hlavna M, et al: Analysis of metallothionein and glutathione in prostate cells as markers of oxidative stress. Int J Mol Med 30: S46-S46, 2012.

23. Aschner M, Conklin DR, Yao CP, Allen JW and Tan KH: Induction of astrocyte metallothioneins (MTs) by zinc confers resistance against the acute cytotoxic effects of methylmercury on cell swelling, $\mathrm{Na}^{+}$uptake, and $\mathrm{K}^{+}$release. Brain Res 813: 254-261, 1998.

24. Cai L and Cherian MG: Zinc-metallothionein protects from DNA damage induced by radiation better than glutathione and copperor cadmium-metallothioneins. Toxicol Lett 136: 193-198, 2003.

25. Min KS, Nishida K and Onosaka S: Protective effect of metallothionein to ras DNA damage induced by hydrogen peroxide and ferric ion-nitrilotriacetic acid. Chem Biol Interact 122: 137-152, 1999.

26. Takahashi S: Molecular functions of metallothionein and its role in hematological malignancies. J Hematol Oncol 5: 41, 2012.

27. Otsuka F, Iwamatsu A, Suzuki K, Ohsawa M, Hamer DH and Koizumi S: Purification and characterization of a protein that binds to metal-responsive elements of the human metallothionein II(a) gene. J Biol Chem 269: 23700-23707, 1994.

28. Smirnova IV, Bittel DC, Ravindra R, Jiang HM and Andrews GK: Zinc and cadmium can promote rapid nuclear translocation of metal response element-binding transcription factor-1. J Biol Chem 275: 9377-9384, 2000.

29. Fan LZ and Cherian MG: Potential role of $\mathrm{p} 53$ on metallothionein induction in human epithelial breast cancer cells. Br J Cancer 87: 1019-1026, 2002.

30. Ostrakhovitch EA, Olsson PE, von Hofsten J and Cherian MG: P53 mediated regulation of metallothionen transcription in breast cancer cells. J Cell Biochem 102: 1571-1583, 2007.

31. Fan S, Smith ML, Rivet DJ, et al: Disruption of p53 function sensitizes breast-cancer MCF-7 cells to cisplatin and pentoxifylline. Cancer Res 55: 1649-1654, 1995. 
32. Woo W and Xu ZM: Body zinc distribution profile during $\mathrm{N}$-methyl-N-nitrosourea-induced mammary tumorigenesis in rats at various levels of dietary zinc intake. Biol Trace Elem Res 87: 157-169, 2002

33. Masarik M, Gumulec J, Hlavna M, et al: Monitoring of the prostate tumour cells redox state and real-time proliferation by novel biophysical techniques and fluorescent staining. Integr Biol 4: 672-684, 2012.

34. Domingo JL, Llobet JM, Paternain JL and Corbella J: Acute zinc intoxication - comparison of the antidotal efficacy of several chelating-agents. Vet Hum Toxicol 30: 224-228, 1988.

35. Kotoh T, Dhar DK, Masunaga R, et al: Antiangiogenic therapy of human esophageal cancers with thalidomide in nude mice. Surgery 125: 536-544, 1999.

36. Xanthopoulos JM, Romano AE and Majumdar SK: Response of mouse breast cancer cells to anastrozole, tamoxifen, and the combination. J Biomed Biotechnol 2005: 10-19, 2005.

37. Kizek R, Trnkova L and Palecek E: Determination of metallothionein at the femtomole level by constant current stripping chronopotentiometry. Anal Chem 73: 4801-4807, 2001.

38. Ellman GL: Tissue sulfhydryl groups. Arch Biochem Biophys 82: 70-77, 1959.

39. Franklin RB and Costello LC: Zinc as an anti-tumor agent in prostate cancer and in other cancers. Arch Biochem Biophys 463 211-217, 2007.

40. Hou G, Dick R, Zeng C and Brewer GJ: Comparison of lowering copper levels with tetrathiomolybdate and zinc on mouse tumor and doxorubicin models. Transl Res 148: 309-314, 2006.

41. Silva MP, Silva DM, Conceicao ALC, Ribeiro-Silva A and Poletti ME: Role of $\mathrm{Ca}, \mathrm{Fe}, \mathrm{Cu}$ and $\mathrm{Zn}$ in breast cancer: study by X-ray fluorescence techniques and immunohistochemical analysis. X-Ray Spectrom 42: 303-311, 2013.

42. Nakshatri H, BhatNakshatri P, Martin DA, Goulet RJ and Sledge GW: Constitutive activation of NF-kappa B during progression of breast cancer to hormone-independent growth Mol Cell Biol 17: 3629-3639, 1997.

43. Uzzo RG, Leavis $\mathrm{P}$, Hatch W, et al: Zinc inhibits nuclear factor-kappa B activation and sensitizes prostate cancer cells to cytotoxic agents. Clin Cancer Res 8: 3579-3583, 2002.

44. Franklin RB and Costello LC: The important role of the apoptotic effects of zinc in the development of cancers. J Cell Biochem 106: 750-757, 2009.

45. Feng P, Li TL, Guan ZX, Franklin RB and Costello LC: Direct effect of zinc on mitochondrial apoptogenesis in prostate cells. Prostate 52: 311-318, 2002.

46. Jones PA and Laird PW: Cancer epigenetics comes of age. Nat Genet 21: 163-167, 1999.

47. Ushijima $\mathrm{T}$ and Okochi-Takada E: Aberrant methylations in cancer cells: where do they come from? Cancer Sci 96: 206-211, 2005.

48. Wallwork JC and Duerre JA: Effect of zinc-deficiency on methionine metabolism, methylation reactions and protein-synthesis in isolated perfused rat-liver. J Nutr 115: 252-262, 1985.

49. Marks PA and Xu WS: Histone deacetylase inhibitors: potential in cancer therapy. J Cell Biochem 107: 600-608, 2009.

50. Finnin MS, Donigian JR and Pavletich NP: Structure of the histone deacetylase SIRT2. Nat Struct Biol 8: 621-625, 2001.

51. Somoza JR, Skene RJ, Katz BA, et al: Structural snapshots of human HDAC8 provide insights into the class I histone deacetylases. Structure 12: 1325-1334, 2004.
52. Fatemi M, Hermann A, Pradhan S and Jeltsch A: The activity of the murine DNA methyltransferase Dnmt1 is controlled by interaction of the catalytic domain with the $\mathrm{N}$-terminal part of the enzyme leading to an allosteric activation of the enzyme after binding to methylated DNA. J Mol Biol 309: 1189-1199, 2001.

53. Zhou Q, Atadja P and Davidson NE: Histone deacetylase inhibitor LBH589 reactivates silenced estrogen receptor alpha (ER) gene expression without loss of DNA hypermethylation. Cancer Biol Ther 6: 64-69, 2007.

54. Shimizu M, Hochadel JF, Fulmer BA and Waalkes MP: Effect of glutathione depletion and metallothionein gene expression on arsenic-induced cytotoxicity and c-myc expression in vitro. Toxicol Sci 45: 204-211, 1998.

55. Feng JF, Lu L, Zeng P, et al: Serum total oxidant/antioxidant status and trace element levels in breast cancer patients. Int J Clin Oncol 17: 575-583, 2012.

56. Kasapovic J, Pejic S, Todorovic A, Stojiljkovic V and Pajovic SB: Antioxidant status and lipid peroxidation in the blood of breast cancer patients of different ages. Cell Biochem Funct 26: 723-730, 2008.

57. Al-Qubaisi MS, Rasedee A, Flaifel MH, et al: Cytotoxicity of nickel zinc ferrite nanoparticles on cancer cells of epithelial origin. Int J Nanomed 8: 2497-2508, 2013.

58. Skrajnowska D, Bobrowska B, Tokarz A, Kuras M, Rybicki P and Wachowicz M: The Effect of Zinc- and copper sulphate supplementation on tumor and hair concentrations of trace elements $(\mathrm{Zn}, \mathrm{Cu}, \mathrm{Fe}, \mathrm{Ca}, \mathrm{Mg}, \mathrm{P})$ in rats with DMBA-induced breast bancer. Pol J Environ Stud 20: 1585-1592, 2011.

59. Mills BJ, Broghamer WL, Higgins PJ and Lindeman RD: Inhibition of tumor-growth by zinc depletion of rats. J Nutr 114: 746-752, 1984

60. Pories WJ, DeWys WD, Flynn A, Mansour EG and Strain WH: Implications of the inhibition of animal tumors by dietary zinc deficiency. Adv Exp Med Biol 91: 243-257, 1977.

61. Dewys W, Pories WJ, Richter MC and Strain WH: Inhibition of Walker 256 carcinosarcoma growth by dietary zinc deficiency. Proc Soc Exp Biol Med 135: 17-22, 1970.

62. McQuitty JT, Dewys WD, Monaco L, et al: Inhibition of tumor growth by dietary zinc deficiency. Cancer Res 30: 1387-1390, 1970.

63. Tang DG and Honn KV: Apoptosis of W256 carcinosarcoma cells of the monocytoid origin induced by NDGA involves lipid peroxidation and depletion of GSH: role of 12-lipoxygenase in regulating tumor cell survival. J Cell Physiol 172: 155-170, 1997.

64. Gardner HA, Kellen JA, Wong AHC, Szalai JP and Katic M Characterization of different cell subpopulations derived from an experimental tumor-model. Cancer Invest 6: 161-165, 1988.

65. Costlow ME, Buschow RA and McGuire WL: Prolactin receptors in an estrogen receptor-deficient mammary-carcinoma. Science 184: 85-86, 1974

66. Kau P, Nagaraja GM, Zheng H, et al: A mouse model for triplenegative breast cancer tumor-initiating cells (TNBC-TICs) exhibits similar aggressive phenotype to the human disease. BMC Cancer 12: 120,2012

67. Drasin DJ, Robin TP and Ford HL: Breast cancer epithelial-tomesenchymal transition: examining the functional consequences of plasticity. Breast Cancer Res 13: 226, 2011.

68. Pulaski BA and Ostrand-Rosenberg S: Mouse 4T1 breast tumor model. Curr Protoc Immunol Chapter 20: Unit 20.2, 2001.

69. Ames BN: Micronutrients prevent cancer and delay aging. Toxicol Lett 103: 5-18, 1998.

70. Ho E: Zinc deficiency, DNA damage and cancer risk. J Nutr Biochem 15: 572-578, 2004. 